\title{
PHYSICO-MECHANICAL AND TRIBOLOGICAL PROPERTIES OF NANOCOMPOSITES AND THEIR VULCANIZATES ON THE BASIS OF MOLYBDENUM DISULPHIDE AND ETHYLENE-PROPYLENE BLOCK COPOLYMER
}

\author{
N.T.Kakhramanov, G.Sh.Gasimova, S.S.Pesetskiy**, A.D.Quliyev, E.V.Dadasheva*, \\ A.A.Qasanova \\ Institute of Polymer Materials, NAS of Azerbaijan \\ * Sumgait State Technical College at Sumgait State University \\ **V.A.Belyi Metal-Polymer Research Institute, NAS of Belarus \\ najaf1946@rambler.ru
}

Received 25.10.2018

\begin{abstract}
The effect of the concentration and size of molybdenum disulphide fine particles on the breaking stress ultimate tensile stress, elongation at break, melt flow index and wear resistance of composite materials based on ethylene-propylene block copolymer and molybdenum disulphide is considered. The possibility of a significant improvement in the properties of nanocomposites by carrying out the crosslinking reaction in a dynamic mode is shown. Nanocomposites patterns of transition from solid to viscous state are investigated by thermomechanical analysis. The optimal concentrations of the reacting components have been established, at which the highest physicomechanical properties of nanocomposites are achieved.
\end{abstract}

Keywords: block copolymer, molybdenum sulphide, thermomechanics, nanocomposites, breaking stress.

Every year, polymeric materials are increasingly used in various fields of industry: machine engineering, shipbuilding, aeronautical engineering, military equipment, space engineering, military space technology, radio engineering and electronic industry. This is since in several parameters polymer materials are significantly superior to steel and non-ferrous metals: chemical resistance, lightness, low cost, satisfactory physical and mechanical characteristics, processability and productivity of plastics processing equipment. This circumstance is made possible by using different methods of purposeful modification of commercially available base polymers [1-4].

Production of composite materials by mixing different types of polymers, the introduction of fine and nano-dispersed fillers in the aggregate made it possible to obtain small batches of polymer composite materials with predetermined properties. It is important to note that it is possible to obtain such composites at virtually all plastics processing plants. The use of special fillers opens the possibility of obtaining composite materials with tribological properties. The use of nanoparticles opens even more new possibilities for changes in a wide range of basic operational characteristics [5-7]. Polyolefins have always been the most fre- quently used research objects as a matrix of composite materials. Of the polyolefins, the most poorly studied ethylene-propylene block copolymer (BEP) was of the greatest interest as a polymer base. In this regard, the purpose of this work was the example of BEP to investigate the effect of concentration and particle size of the filler on the structure and properties of polymer composites.

\section{Experimental part}

The ethylene-propylene block copolymer brand HB240P (BEP) - it is a chain of propylene molecules interrupted by a chain of ethylene-propylene copolymer. They have high impact strength (at low temperatures) and high elasticity, increased long-term thermal stability, resistance to thermal-oxidative destruction during the production and processing of polypropylene, as well as during operation of the product from it. Parameters of characteristics BEP has the following values breaking stress $-25.6 \mathrm{MPa}$, elongation at break $-200 \%$, melt flow index $-0.61 \mathrm{~g} / 10$ min, Vicat softening point $-148^{\circ} \mathrm{C}$, melting point $-166^{\circ} \mathrm{C}$.

Molybdenum disulphide $\left(\mathrm{MoS}_{2}\right)$ is an inorganic binary chemical compound of tetravalent molybdenum with bivalent sulphur. $\mathrm{MoS}_{2}$ is a black crystalline powder, oily to the touch, hardness 1.3 on the Mohs scale. In molybdenum 
disulphide, each $\mathrm{Mo}^{(\mathrm{IV})}$ atom is located in the center of a trigonal prism and is surrounded by six sulphur atoms. The trigonal prism is oriented so that in the crystal the molybdenum atoms are between two layers of sulphur atoms. Due to the weak Van der Waals interaction forces between the sulphur atoms in $\mathrm{MoS}_{2}$, the layers can easily slide relative to each other. This leads to a lubricating effect.

$\mathrm{MoS}_{2}$ particles of various sizes, up to nanoscale, were obtained in an analytical mill A11 at a maximum rotor speed of $28000 \mathrm{rpm}$. The longer the grinding time was, the smaller the $\mathrm{MoS}_{2}$ particles were obtained. In the process of grinding $\mathrm{MoS}_{2}$, particles of the following sizes were obtained: $25-120,500-900$ and $1200-2500 \mathrm{~nm}$.

The particle size of $\mathrm{MoS}_{2}$ was determined on the instrument model STA PT1600 Linseiz Germany and was $14-110 \mathrm{~nm}$.

Dicumyl peroxide (PD) is a light yellow powder, $T_{\mathrm{m}}=40^{\circ} \mathrm{C}$, designed to produce crosslinked structures in polymer blends.

The method of obtaining polymer composites. Carefully weighed samples of the polymer matrix and nano-dispersed filler powder are mixed in hot rollers at a temperature of 140$180^{\circ} \mathrm{C}$ for $7-8$ minutes. The resulting composites are pressed at a temperature of $180-190^{\circ} \mathrm{C}$. Dumb bell samples are cut down from the obtained plates to study the physico-mechanical characteristics of polymer nanocomposites in accordance with GOST 17370-71.

When constructing the thermomechanical curve of the polymer $\Delta=f(T)$, it is very important to cover, as far as possible, the entire temperature range of the polymer - glassy (crystalline), highly elastic and viscous states. Thermomechanical curves reflect all possible physical, physicochemical and chemical processes occurring in the sample because of changes in the temperature of the experiment and, thus, provide reliable information on temperature transitions that are important for polymer processing. Physico-mechanical characteristics were determined by standard methods: tensile yield stress and elongation at break in accordance with GOST 11262-80.

The gel fraction of cross-linked BEPbased samples was separated on a Soxhlet in- strument by washing the samples at the boiling point of $o$-xylene. The difference in the mass of the sample before and after washing was determined by the content of the gel fraction.

The melt flow rate (MFR) was determined on a rheometer of the brand MELT FLOW TESTER, CEAST MF50 (INSTRON, Italy) at a temperature of $190^{\circ} \mathrm{C}$ and a load of 5 $\mathrm{kg}$. The wear resistance of the composites was investigated on an abrazimeter. Path length 44 m, load 6N, abrasive paper P500.

\section{Results and discussion}

In the process of research, the structure and properties of polymer composites need to have data on the influence of the size of the filler particles on their physico-mechanical properties. In this case, it will be possible to identify significant differences in the nature of changes in properties and to carry out the selection of the optimal formula of the composite with the predicted performance characteristics. Table 1 presents the results of a study of the properties of composites based on BEP depending on the size and concentration of dispersed $\mathrm{MoS}_{2}$ particles. From a comparative analysis of the data presented in this table, it can be established that the BEP $+\mathrm{MoS}_{2}$ nanocomposites have relatively better physico-mechanical and tribological characteristics. It should be noted that with an increase in the particle size of $\mathrm{MoS}_{2}$ from nanoscale to $2500 \mathrm{~nm}$, a regular deterioration of the physico-mechanical properties and wear resistance of composite materials is observed. Regardless of the size of the filler particles, the introduction of 1.0-5.0 mass \% of $\mathrm{MoS}_{2}$ is accompanied by an increase in the physico-mechanical characteristics. This is interpreted by the fact that BEP is a semicrystalline polymer with a degree of crystallinity of $61 \%$. In the melt of a polymer composite with a minimum concentration of nanoparticles of the filler, they behave like structure-forming agents, thereby creating nucleation centers.

The advantage of nanoparticles is that they are commensurate with the size of the primary crystalline formations, because of which the process of orientation of macrochains on their surface proceeds with greater efficiency [7]. 
Table 1. The effect of the concentration and size of particles $\mathrm{MoS}_{2}$ on the properties of composites based on BEP

\begin{tabular}{|c|c|c|c|c|c|c|}
\hline №№ & $\begin{array}{c}\text { Formula of polymer } \\
\text { composite } \\
\left(\mathrm{BEP}+\mathrm{MoS}_{2} \text {, mass \%) }\right.\end{array}$ & $\begin{array}{c}\text { Breaking } \\
\text { stress, } \\
\text { MPa }\end{array}$ & $\begin{array}{c}\text { Elongation } \\
\text { at break, } \\
\%\end{array}$ & $\begin{array}{l}\text { MFI, } \\
\mathrm{g} / 10 \mathrm{~min}\end{array}$ & $\begin{array}{l}\text { Wear in the } \\
\text { first cycle, } \\
\mathrm{mg}\end{array}$ & $\begin{array}{c}\text { Particle size, } \\
\mathrm{nm}\end{array}$ \\
\hline 1 & BEP & 25.6 & 200 & 0.61 & 144.12 & - \\
\hline 2 & $\mathrm{BEP}+1.0$ & 29.8 & 255 & 2.04 & 87.33 & $25-120$ \\
\hline 3 & $\mathrm{BEP}+5.0$ & 31.3 & 185 & 3.88 & 78.45 & $25-120$ \\
\hline 4 & $\mathrm{BEP}+10.0$ & 30.4 & 145 & 4.21 & 62.28 & $25-120$ \\
\hline 5 & $\mathrm{BEP}+20.0$ & 23.5 & 75 & 5.32 & 55.29 & $25-120$ \\
\hline 6 & $\mathrm{BEP}+30.0$ & 19.7 & 45 & 4.97 & 65.13 & $25-120$ \\
\hline 7 & $\mathrm{BEP}+1.0$ & 28.4 & 215 & 1.05 & 112.32 & 500-900 \\
\hline 8 & $\mathrm{BEP}+5.0$ & 29.6 & 170 & 1.83 & 93.16 & $500-900$ \\
\hline 9 & $\mathrm{BEP}+10.0$ & 27.8 & 95 & 2.16 & 88.36 & $500-900$ \\
\hline 10 & $\mathrm{BEP}+20.0$ & 22.2 & 60 & 1.98 & 93.88 & $500-900$ \\
\hline 11 & $\mathrm{BEP}+30.0$ & 19.0 & 45 & 1.21 & 95.15 & $500-900$ \\
\hline 12 & $\mathrm{BEP}+1.0$ & 27.4 & 190 & 0.94 & 133.57 & $1200-2500$ \\
\hline 13 & $\mathrm{BEP}+5.0$ & 28.7 & 170 & 1.87 & 117.79 & $1200-2500$ \\
\hline 14 & $\mathrm{BEP}+10$ & 28.5 & 75 & 1.32 & 103.18 & $1200-2500$ \\
\hline 15 & $\mathrm{BEP}+20$ & 21.7 & 55 & 0.93 & 102.86 & $1200-2500$ \\
\hline 16 & $\mathrm{BEP}+30$ & 18.2 & 30 & 0.65 & 114.97 & $1200-2500$ \\
\hline
\end{tabular}

The latter circumstance was confirmed by a noticeable increase in the breaking stress of the samples with a filler concentration in the range of 1-5 mass \%. Thus, not only homogeneous, but also heterogeneous nucleation centers are formed in polymer materials. There is reason to believe that in the process of cooling a nanocomposite, at the initial moment, the macrochains crystallize at heterogeneous, and then at homogeneous centers. If the filler concentration above 10 mass $\%$ occurs a sharp decrease in breaking stress and elongation at break of samples. Apparently, during the cooling nanocomposite melt at these centers is formed spherulitic crystalline formations which displace nanoparticles into the amorphous interspherulite space during growth. And, the more particles of the filler are displaced into the inter-spherulite space, the more steric difficulties arise for the "through passage" chains, which determine the deformation characteristics of nanocomposites [8]. Indeed, when the concentration of filler of more than 10 mass \% there is a sharp decrease in elongation at break and ultimate tensile stress. With the introduction of 1.0 mass $\% . \mathrm{MoS}_{2}$, the latter, like the structurant, helps to obtain finespherulitic structural formations, which, as is well known, contribute to the improvement of the deformation-strength properties of composite materials. Analyzing the data presented in Table 1, it can be established that regardless of the size of the filler particles with the introduction of up to 30 mass $\% . \mathrm{MoS}_{2}$ in the composition of the polymer matrix, an increase in the MFI of the samples with respect to the initial BEP is observed. This circumstance can be interpreted by the peculiarities of the structure of $\mathrm{MoS}_{2}$, which, as is known, has a layered structure, which has a positive effect on improving the wear resistance of the composite material. The only difference is that $\mathrm{MoS}_{2}$ nanoparticles contribute relatively more to the increase in the MFI of the samples. It should be noted that with the same $\mathrm{MoS}_{2}$ concentration in the composite, the number of nanoparticles per unit of polymer volume is much higher compared to dispersed particles with a size of 1200-2500 nm. In this regard, the number of heterogeneous nucleation centers responsible for the formation of finespherulitic crystalline formations increases in nanocomposites. Therefore, in fact, the process of flow of composites is an aggregate flow of a physically structured melt.

To improve the strength properties and wear resistance of polymer materials, in some cases it becomes the most useful research aimed at obtaining chemically cross-linked composite materials $[9,10]$. The possibility of forming a spatial structure of varying degrees in filled systems will allow purposefully making changes to certain characteristics of the nanocomposite. For example, Table 2 presents the results of experimental studies on the effect of dicumyl peroxide (DP) concentration on the properties of nanocomposites. 
Table 2. Effect of DP concentration on the crosslinking process and properties of nanocomposites on the basis of BEP and $\mathrm{MoS}_{2}$

\begin{tabular}{|l|c|c|c|c|c|}
\hline $\begin{array}{c}\text { Formula of polymer composite } \\
\text { BEP+ mass \% MoS }+ \text { mass \% } \\
\text { DP }\end{array}$ & $\begin{array}{c}\text { Breaking } \\
\text { stress, } \\
\text { MPa }\end{array}$ & $\begin{array}{c}\text { Elongation at } \\
\text { break, } \\
\%\end{array}$ & $\begin{array}{c}\text { MFI, } \\
\text { g/10 min }\end{array}$ & $\begin{array}{c}\text { Wear in the } \\
\text { first cycle, } \\
\text { mg }\end{array}$ & $\begin{array}{c}\text { Gel frac- } \\
\text { tion, } \\
\text { mass } \%\end{array}$ \\
\hline BEP+0.5DP & 28.2 & 125 & 0.32 & 123.13 & 25 \\
BEP+1.0DP & 27.9 & 20 & don't flow & 101.76 & 47 \\
BEP+10 $\mathrm{MoS}_{2}+0.2 \mathrm{DP}$ & 32.2 & 90 & 0.85 & 37.17 & 13 \\
$\mathrm{BEP}+10 \mathrm{MoS}_{2}+0.5 \mathrm{DP}$ & 35.6 & 55 & 0.41 & 33.14 & 29 \\
$\mathrm{BEP}+10 \mathrm{MoS}_{2}+1.0 \mathrm{DP}$ & 29.8 & 15 & 0.14 & 51.45 & 50 \\
$\mathrm{BEP}+10 \mathrm{MoS}_{2}+2.0 \mathrm{DP}$ & 17.5 & - & don't flow & 55.97 & 74 \\
\hline
\end{tabular}

As the object of the study was taken initial BEP nanocomposite with 10 mass \%. $\mathrm{MoS}_{2}$, since it is precisely at this concentration of filler that the greatest strength and wear resistance of the composite material was ensured. From a comparative analysis of the data presented in Table 2, it can be noted that with an increase in the concentration of DP from 0.5 to 1.0 mass \%, a decrease in the value of the physicomechanical parameters of the initial BEP is observed. Exceptions are wear resistance values, which in BEP cross-linked samples are improved by 15 $29 \%$. A comparative analysis of the wear resistance of nanocomposites in Tables 1 and 2 allows us to establish that some improvement occurs because of crosslinking, i.e. decrease in the value of this parameter, especially with a low content of DP, equal to $0.2-0.5$ mass $\%$.

Apparently, in this case, an improvement in the wear resistance of cross-linked nanocomposites by 4.3 times becomes possible during the formation of a rare-network cross-linked structure. As can be seen from this table, with increasing concentrations of DP in nanocomposites properties vary according to a certain regularity. The maximum value of the ultimate tensile stress, equal to $35.6 \mathrm{MPa}$, is achieved with the introduction of 0.5 mass $\%$. DP into the composition. A further increase in the concentration of DP is accompanied by a decrease in the ultimate tensile stress and elongation at break of nanocomposites. This is explained by the fact that when using DP (over 0.5 mass \%), cross-linking that occurs in the melt mode makes it difficult to create not only heterogeneous, but also homogeneous nucleation centers. The latter circumstance ultimately manifests itself in slowing down the process of crystalli- zation of macrochains from the melt, accompanied by a decrease in the crystallinity of nanocomposites and the occurrence of steric difficulties in the formation of a fine-spherulitic supermolecular structure. Together, all these facts contribute to the deterioration of the deformation-strength properties of nanocomposites. This is confirmed by the results of the study of gel fraction of nanocomposites. As can be seen from table 2, with an increase in the concentration of DP from 0.2 to 2.0 mass $\%$, a regular increase in the gel fraction content in the composition of nanocomposites from 25 to $74 \%$ occurs with a corresponding expected decrease in the MFI. At the same time, if the introduction of 1.0 mass \% DP completely prevents the ability of the initial BEP to melt flow, then in the crosslinked filled composites the samples still retain the ability to be processed.

For a better understanding of the processes occurring in the polymer composites was of interest using a thermomechanical measurement method is more elaborate study on their physical states depending on the temperature, concentration and particle size of the filler. Figure 1 illustrates the thermomechanical characteristics of nanocomposites based on BEP and $\mathrm{MoS}_{2}$. Analyzing the thermal deformation curves of nanocomposites in this figure, it can be noted that the introduction of even 1.0 mass $\% . \mathrm{MoS}_{2}$ helps to increase the softening temperature of the sample from 144 to $146^{\circ} \mathrm{C}$. A further increase in the concentration of $\mathrm{MoS}_{2}$ from 1.0 to 30.0 mass \% leads to an increase in the softening onset temperature to $168^{\circ} \mathrm{C}$. At the same time, within the concentration of the filler from 1.0 to 10.0 mass $\%$ thermomechanical curves pass from solid to viscous-fluid state. At $\mathrm{MoS}_{2}$ concentration over 
10.0 mass $\%$ on a thermomechanical curve in the region of a viscous state, a small plateau is formed. And, the greater the concentration of $\mathrm{MoS}_{2}$ in the composite, the more stretched this area in the viscous state on the temperature scale, which clearly indicates a high melt viscosity and the existence of a good adhesive bond between the oriented macrochains of the matrix with the surface of nanoparticles.

For a comparative analysis, Figure 2 shows the thermomechanical curves of BEP + $\mathrm{MoS}_{2}$ composites with a filler particle size of $1200-2500 \mathrm{~nm}$. Identifying the data in this Figure, it can be noted that in this case, with an increase in the concentration of $\mathrm{MoS}_{2}$, a regular change in the thermo-deformation curves is observed, accompanied by stretching of the viscous flow area on the temperature scale. The softening temperature of the samples accordingly varies from 146 to $160^{\circ} \mathrm{C}$. Comparing the

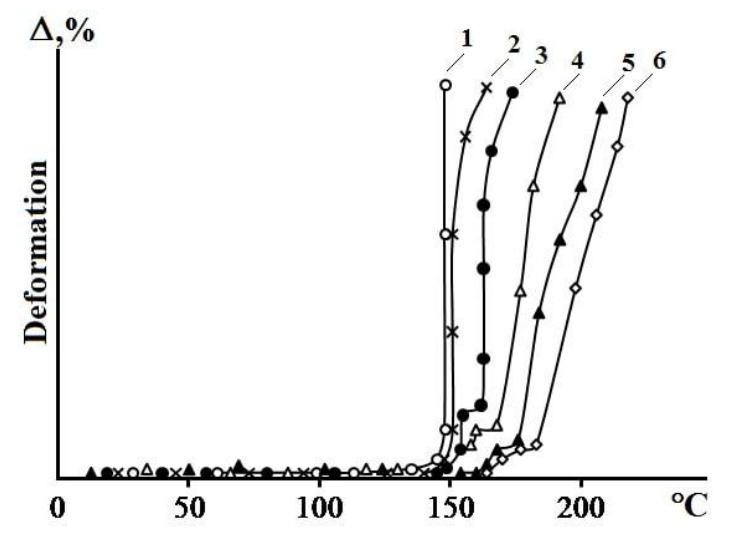

Fig.1. The thermomechanical curves of nanocomposites on the basis of BEP depending on $\mathrm{MoS}_{2}$ concentrations (mass \%) with a nanoparticle size of 25-120 nm: ○ - initial BEP (1), $\times-1 \%(2), \bullet-$ $5 \%$ (3), $\Delta-10 \%$ (4), $\Delta-20 \%$ (5), $\diamond-30 \%$ (6).

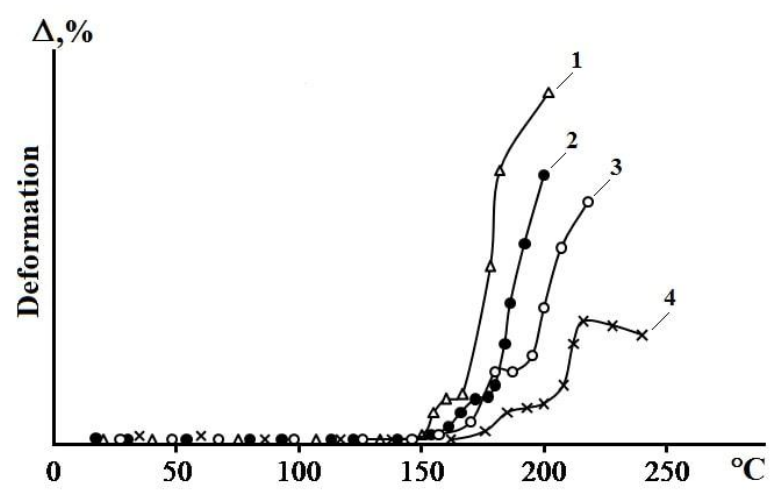

thermomechanical curves in Figures 1 and 2, it can be established that with the same maximum deformation of the sample, the nanoparticles stretch the viscous state (up to $168^{\circ} \mathrm{C}$ ) to a greater extent on the temperature scale compared to the fine $\mathrm{MoS}_{2}$ particles (up to $160^{\circ} \mathrm{C}$ ).

Method thermomechanical research gives a capacious understanding of the processes occurring in the solid and viscous-flow areas of composite materials exposed to crosslinking agents. For comparison, Figure 3 shows the thermomechanical curves of cross-linked samples of nanocomposites on the basis of BEP and $\mathrm{MoS}_{2}$. Analyzing the presented results of studies in this figure, it can be noted that with an increase in the concentration of DP in the composition of the composite in the field of viscous flow, there are quite dramatic changes in the patterns of change in thermodeformation curves.

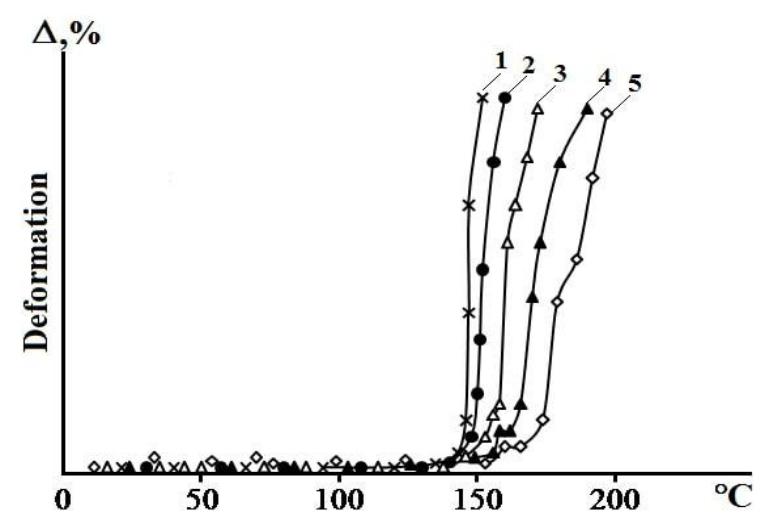

Fig.2. The thermomechanical curves of composites based on BEP depending on $\mathrm{MoS}_{2}$ concentrations with a particle size of 1200-2500 nm: $\times-$ $1 \%(1), \bullet-5 \%$ (2), $\Delta-10 \%$ (3), $\Delta-20 \%$ (4), $\diamond-30 \%(5)$.

Fig.3. Thermomechanical curves of nanocomposites based on BEP +10 mass $\% \mathrm{MoS}_{2}$ depending on the concentration of DP: $\Delta-$ initial $\mathrm{BEP}+10 \% \mathrm{MoS}_{2}(1), \bullet-0.2 \%$ DP (2), ० - 0,5\% DP (3), $\times-1.0 \%$ DP (4). 
It is characteristic that an increase in the concentration of DP is accompanied by a stretching of the region of a viscous flow state. Nanocomposites with DP concentrations up to 0.5 mass \% still retain the ability to transition into the viscous-fluid state. Further increase in the concentration of the cross-linking agent leads to the fact that the material practically loses its ability to go into a plastic state, that is, it goes into a glassy state.

Thus, based on the above, we can conclude that, unlike conventional fine fillers, nanoparticles make a significant contribution to the nature of the changes in the physicomechanical and thermomechanical properties of composite materials. It becomes obvious that the size of the filler particles has become the determining factor that must be considered when conducting comprehensive studies of the properties of composite materials. The influence of filler particles begins with the process of the emergence in the matrix melt of heterogeneous crystallization centers with the subsequent formation of small-spherulite crystalline formations on their basis. The use of crosslinking agents in fact showed how sensitive the polymer base is to changes in the structure and, accordingly, in the properties of nanocomposites. It has been established that with minimum DP concentrations (up to 0.5 mass \%), it becomes possible to significantly influence the improvement of the main physico-mechanical characteristics of nanocomposites, while maintaining the acceptable level of MFI.

\section{References}

1. Berlin A.A., Volfson S.A., Oshman V.G. Printcipy sozdaniia kompozitcionnykh materialov. M.: Himiia, 1990. $240 \mathrm{~s}$.

2. Gorohovskii A.V. Kompozitnye materialy. Sarahtovskii gos. tekhnicheskii un-t, 2008. 73 s.

3. Simonov-Emelianov I.D., Kuleznev V.N. Os-novy sozdaniia kompozitcionnykh materialov. M.: MIKHM, 1986. $64 \mathrm{~s}$.

4. Kakhramanov N.T., Kakhramanly Iu.N. Nanotekhnologiia $\mathrm{v}$ oblasti materialovedeniia. "Uchenye Zapiski. Natcionalnaia Aviatc. Akademiia Azerbaidzhana. 2009. T.11, № 3. S. 7-15.

5. Ivanchev S.S., Ozerin A.N. Nanostruktury v polimernykh sistemakh. //Vysokomolek. soed. 2006. B. T. 48. № 8. S. 1541-1544.

6. Kodolov V.I., Khokhriakov N.V. Kuznetsov A.P. Perspectives of nanostructure and nanosystems application when creating composites with predicted behavior. In the book: Space challenges in XXI century. V. 3. Novel materials and technologies for space rockets and space development. M.: Torus press. 2007. P. 201-205.

7. Pomogailo A.D. Gibridnye polimer-neorganicheskie nanokompozity //Uspehi himii. 2000. T. 69. № 1. S. 60.

8. Kodolov V.I., Hokhriakov N.V., Kuznetcov A.P. $\mathrm{K}$ voprosu o mehanizme vliianiia nanostruktur na strukturno izmeniaiushchiesia sredy pri formirovanii "intellektualnykh" kompozitov // Nanotekhnika. 2006. T. 7. № 3. S. 27-35.

9. Okhlopkova T.A., Okhlopkova A.A., Spiridonov A.M., Nikiforov L.A. Ctrukturnye izmeneniia sverkhvysokomolekuliarnogo polietilena pod vozdeistviem keramicheskikh nanodispersii //Voprosy materialovedeniia. 2014. T. 79. № 3. S. 145-153.

10. Okhlopkova A.A., Okhlopkova T.A., Borisova R.V. Upravlenie protcessami strukturoobrazovaniia $\mathrm{V}$ polimernykh kompozitcionnykh materialakh na osnove SVMPE //Nauka i obrazovanie. 2015. T. 78. № 2. S. 73-78.

\section{MOLIBDEN DISULPHID VӘ ETILEN-PROPILEN BLOK-BİRGOPOLIMERİ OSASINDA NANOKOMPOZITLəRIN Və ONLARIN VULKANIZATLARININ FIZIIKI-MEXANIKİ Və TRIBOLOJI XASSӘLӘRİ}

\section{N.T.Qəhrəmanov, G.Ș.Qasımova, S.S.Pesetskiy, A.D.Quliyev, E.V.Dadașeva, A.Ә.Həsənova}

Etilen-propilen blok birgəpolimeri əsasında alınan kompozit materialların dartılmada möhkəmlik həddinə, nisbi uzanmasına, ərintinin axıcı göstəricisinə və sürtünməyə qarşı davamlılı̆̆ına molibden disulphidin miqdarının və xırdadispers hissəciklərinnin ölçüsünün təsiri öyrənilmişdir. Tikilmə reaksiyasının dinamik rejimində aparılması nəticəsində nanokompozitlərin xassələrinin əhəmiyyətli dərəcədə yaxşılaşdırılmasının imkanları göstərilmişdir. Termomexaniki analiz üsulu ilə nanokompozitlərin bərk haldan özlüaxıcı hala keçməsinin qanunauyğunluqları tədqiq edilmişdir. Nanokompozitlərin daha yüksək fiziki-mexaniki xassələrinin əldə olunduğu komponentlərin optimal miqdarları müəyyən edilmişdir.

Açar sözlor: blok birgapolimer, molibden sulphid, termomexanika, nanokompozit, dartılmada möhkamlik haddi. 


\title{
ФИЗИКО-МЕХАНИЧЕСКИЕ И ТРИБОЛОГИЧЕСКИЕ СВОЙСТВА НАНОКОМПОЗИТОВ И ИХ ВУЛКАНИЗАТОВ НА ОСНОВЕ ДИСУЛЬФИДА МОЛИБДЕНА И БЛОК-СОПОЛИМЕРА ПРОПИЛЕНА С ЭТИЛЕНОМ
}

\author{
Н.Т.Кахраманов, Г.Ш.Гасымова, С.С.Песецкий, А.Д.Гулиев, Э.В.Дадашева, А.А.Гасанова
}

Рассмотрено влияние концентрации и размера мелкодисперсных частиц дисульфида молибдена на разрушающее напряжение, относительное удлинение, показатель текучести расплава и износостойкость композитных материалов на основе блок-сополимера пропилена с этиленом и дисульфида молибдена. Показана возможность существенного улучшения свойств нанокомпозитов путем проведения реакции сшивания в динамическом режиме. Методом термомеханического анализа исследованы закономерности перехода нанокомпозитов из твердого в вязкотекучее состояние. Установлены оптимальные концентрации реагирующих компонентов, при которых достигаются наилучшие физико-механические свойства нанокомпозитов.

Ключевые слова: блок-сополимер, сульфид молибдена, термомеханика, нанокомпозиты, разрушающее напряжение. 